\title{
Spatio-Temporal Variation Study of Physico -Chemical Parameters Characterizing Water Quality of Oued M'zab Region, Algeria
}

\author{
Zohra Baba Amer ${ }^{1 *}$, Zineb Ben Saha ${ }^{1}$, Abdelkrim Hazzab ${ }^{2}$ \\ ${ }^{1}$ Faculty of Sciences and Technology, Department of Sciences and Technology, \\ University of Ghardaia, Algeria \\ ${ }^{2}$ Laboratory of Modeling and calculation methods. University of Dr. Moulay Tahar Saida, Algeria. \\ * Corresponding author email: babaamerz@yahoo.fr
}

Received: 20 August 2016 / Revised: 07 September 2016 / Accepted: 12 September 2016 / Published: 19 September 2016

\begin{abstract}
A B S T RA C T
This work involves the study of hydrological characteristics of the groundwater of Oued M'zab, due to the domestic, agricultural, and industrial pollution. The different sampling points are located upstream and downstream of the river. Water samples of groundwater were taken monthly at stations spread over the flow of the river. The wells are distributed throughout the course of the flow of the river. The measured hydrological parameters (temperature, salinity, suspended particles) showed significant monthly variations with a high concentration of total suspended solids which reached $71.72 \mathrm{mg} \backslash 1$. The same results indicate that the groundwater is rich in minerals and nutritious elements while on the set of sampled points only salinity showed significant variations. The maximum value of the sulphate with a concentration of approximately $2597 \mathrm{mg} \backslash 1$. The chlorides and sodium concentrations reach respectively the values of $1633 \mathrm{mg} \backslash 1$ and $1970 \mathrm{mg} \backslash 1$. This indicates that the infiltration of water of M'zab contains several pollutants contributing to the degradation of the quality of groundwater, Hence the need for preventive measures, conservative and prospects to preserve our layer from pollution.
\end{abstract}

Keywords: Oued M'zab Region; pollution, contamination, industrial waste, groundwater, salinity.

\section{Introduction}

As part of the implementation of a master plan for the preservation of the environment from pollution factors, today the focus is increasingly on examining the effects of discharges agriculture waste into surface water and groundwater [1-3]. Public surveys indicate that a massive and uncontrolled pollution both by natural organic matter and industrial products are observed. The pollution is generated notably by the important demographic expansion, and on the other hand the economic boom in all the region, Algeria [4]. The pollution has been associated with a growing demand for water [5] in recent years, and due to the low rainfall $[6,7]$.

\subsection{The Valley of Oued M'zab}

In the Algerian Sahara, drinking water is supplied exclusively by groundwater in aquifers and Continental Terminal complex Interleave (Albian water) [6]. The region of M'zab is part of the district of Ghardaia, in the middle of the northern Sahara basin. The distric of Ghardaia is like any other province of Algeria, experiencing a major industrial development. However, this development has not been without its negative consequences on the environment of the province including the Oued M'zab valley. This situation has led to the need for a study of the current situation with treats and identifying pollution sources. The Oued M'zab, one of the 
Spatio-Temporal Variation Study of Physico -Chemical Parameters Characterizing Water Quality of Oued M'zab Region, Algeria

major rivers of the Sahara, is a concrete example of this type of pollution problem. The Geological and schematic section of the valley M'zab is shown in Figure 1.

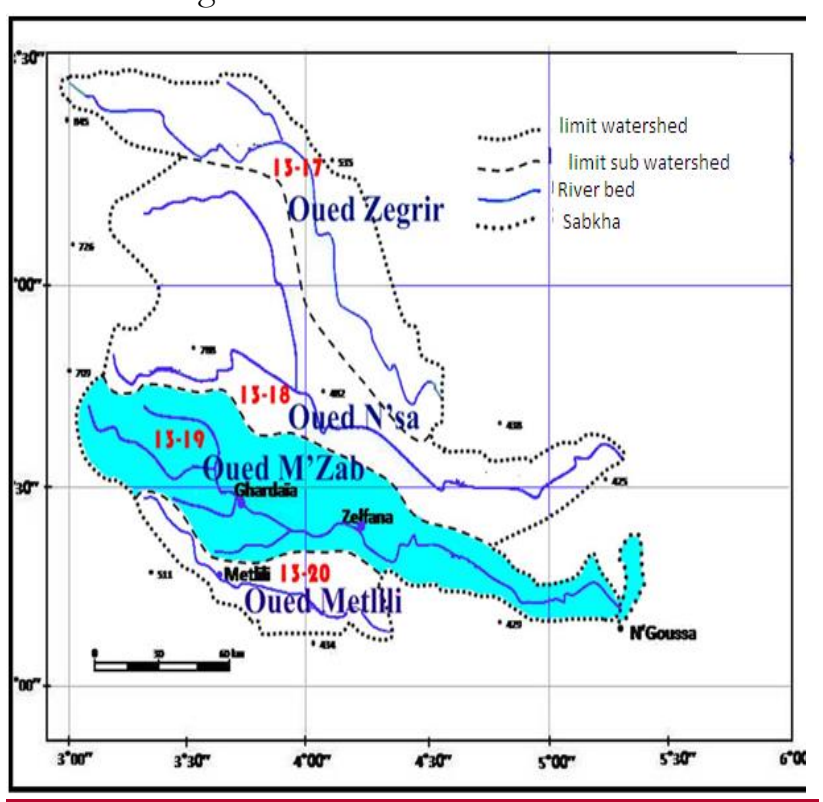

Figure 1: The Geological and schematic section of the valley M'zab (source: ARNH 2003) [8]

Through its hydro-morphological characters, it is a stream of critical importance both for humans and for aquatic life. Its course of flow are within large cities (Daia, Ghardaia, Ben Isguen, Bounoura and El Atteuf) and large industrial units (Prochisa, ERB, Sorecal, Naftal), locating at the highest point of the palm of Beni Isguen, spilling without treating their domestic and industrial wastewater in the receiving environment, thus Le constituting a danger to the river itself and the environment, especially for the city of El Atteuf which is the area 's receipt of all industrial and domestic waste of the country. The Irrigation of palm trees and crops was done for a long time from groundwater through traditional wells, but this wealth (palmerai and aquifer) did not escape from the aggressiveness of wastewater and industrial water. The watershed of Oued M'zab (Figure 2) is located in the northern Algerian Sahara in the district of Ghardaia, which projected area is $1330 \mathrm{~km}^{2}$. A length of the contour is $253 \mathrm{~km}$ and its compactness index $\mathrm{K}$ $=1.94\left(\mathrm{~K}=0.28 \mathrm{P} / \mathrm{A}^{112}\right)$. It is characterized by high aridity of the soil; it experienced several floods causing considerable human and material losses $(1901,1920,1937,1951,1994,2008)$ [9].

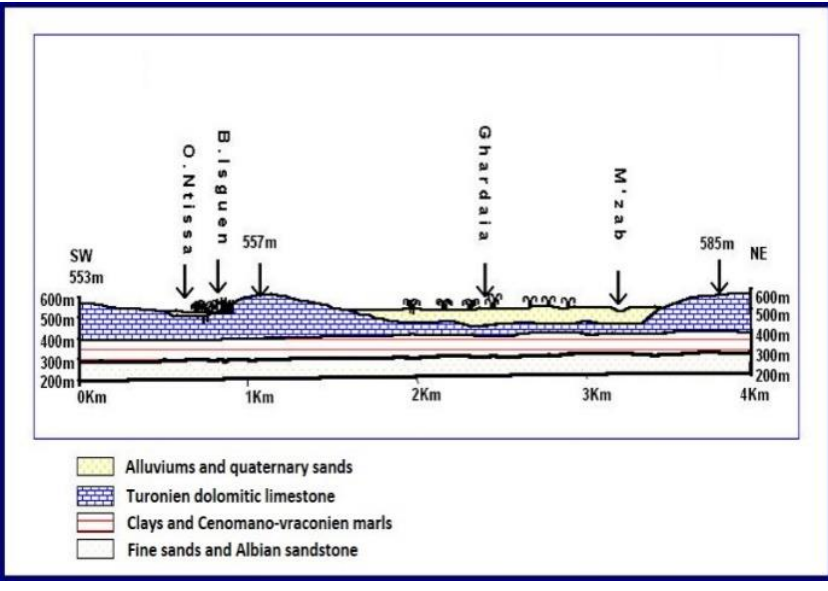

Figure 2: The watershed of the River Oued M 'Zab

\section{Method and Analysis}

Industrial wastes, liquids and solids discharged without treatment of wastewater to the recipient is a danger to groundwater and the environment downstream [10-12]. Through this work we will try to describe the current state of water quality of the water phreatic under industrial units. The most sensitive and important sampling sites are selected according to the direction of flow of the river.

\subsection{Sampling Strategy}

According to the regulations, the analysis is carried out in the official laboratories of the water, Algeria Ghardaia, arguing to the realization of the water characterization operation [13, 14]. Analysis of 7 parameters which includes; depth, temperature, oxygen, $\mathrm{pH}$, conductivity, salinity and turbidity has been measured on the site, while the other parameters which are $\mathrm{K}^{+}, \mathrm{Na}^{+}, \mathrm{Mg}^{+2}$, $\mathrm{Ca}^{+2}$, alkalinity, $\mathrm{NH}_{4}{ }^{+}, \mathrm{NO}_{2}{ }^{-} \mathrm{NO}_{3}{ }^{-}, \mathrm{O} . \mathrm{PO}_{4}{ }^{-3}$, TSS, $\mathrm{BOD}$ and $\mathrm{COD}$ has been analysed in the laboratory according to standards on water surface samples and transported at $4^{\circ} \mathrm{C}$. In order to assess the quality of the physico-chemical characteristics of ground water and to assess the effects of pollutants release, thirty-two wells were selected (Figure 3). This selection has been made considering the importance of use, and taking into account the direction of flow of the river and wastewater. Furthermore, for a representative sampling, sampling wells were spread over a distance of $50 \mathrm{~km}$ with a depth varies between 2.5 and $45 \mathrm{~m}$. 


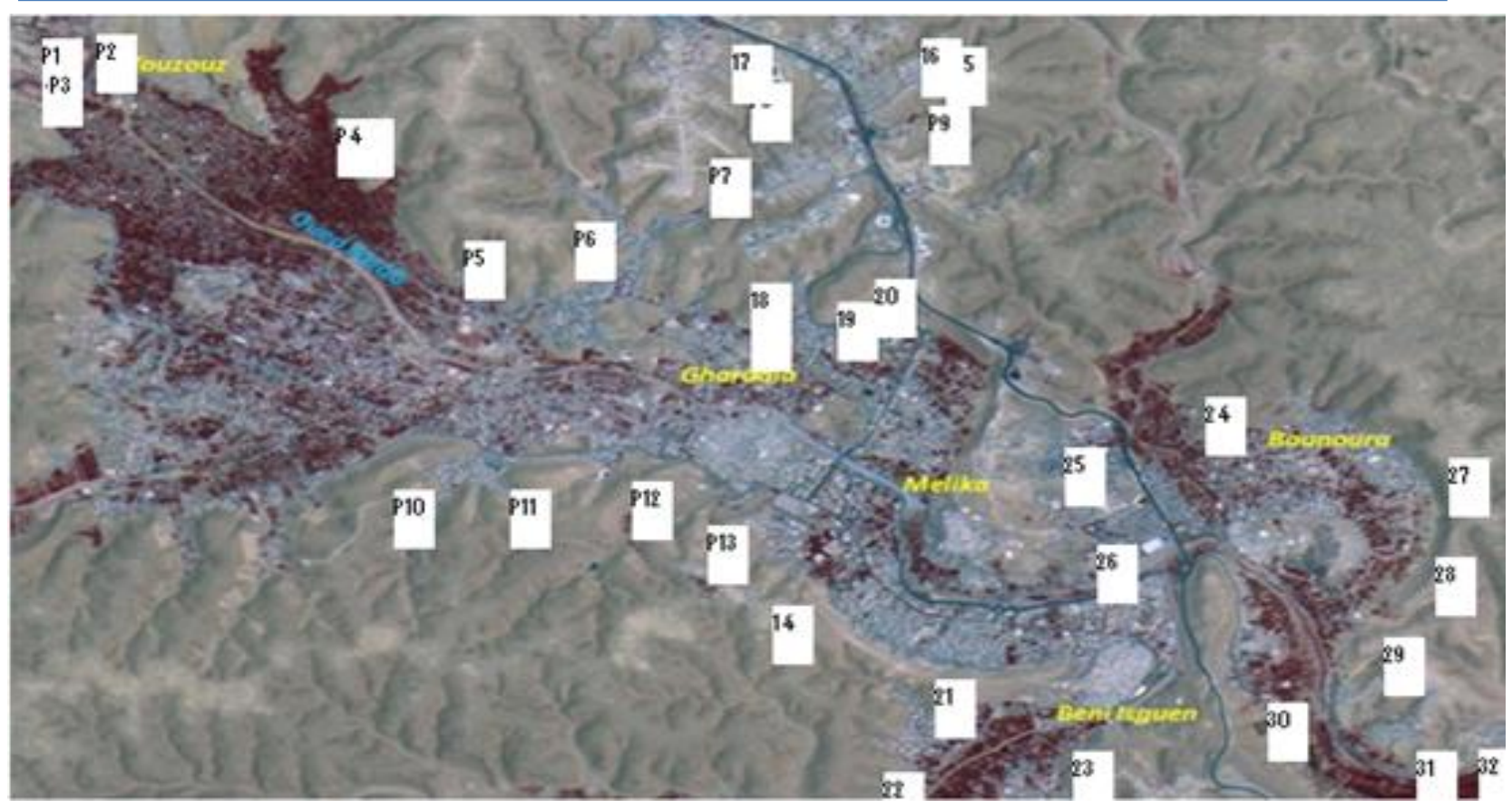

Figure 3: Distribution of the sampling wells in the valley of oued M'zab

\section{Results and Discussion}

Analysis is performed in the dry season (August). This is the most appropriate time to examine the influence of rising temperature. This is particularly useful to determine the influence of high temperature which favours the growth of microorganisms. Because of the instability of the balance related to human disturbance, the groundwater is characterized by a chemical quality which is very difficult to define. These chemical characteristics are sometimes erratic and often one-off, invisible and uncontrollable. While deep water is more stable and the chemical quality depends solely on the lithology of the thermodynamic equilibrium of the elements (rock-solution) [15]. Exploring analysis show firstly that the temperature varies between $11.2^{\circ} \mathrm{C}$ in December and $29.9^{\circ} \mathrm{C}$ in August. The aspect of this variation is related to local conditions (climate, sunshine duration, rate) $[16,17]$. On the other hand, the examination of the variation of the $\mathrm{pH}$ shows that it is from 6.52 to 7.29 . All these values are in line with WHO standards (6.5-8.5) and all the water samples in the same $\mathrm{pH}$ indicator of the stability balanced between the different forms carbonic acid [18] shows consistency along the whole flow of the river. This should probably be attributed to the complex phenomenon buffer carbonatebicarbonate. The conductivity of the water wells examined varies between 1.4 and $8.3 \mathrm{~ms} \backslash \mathrm{cm}^{2}$ (Table1).
Table 1: Statistical analytical data

\begin{tabular}{|c|c|c|c|c|}
\hline & Max. & Min. & Avg. & St. Dev. \\
\hline $\begin{array}{l}\text { Conductivity } \\
\text { ms } \backslash \mathrm{cm}\end{array}$ & 8.34 & 1.41 & 4.87 & 1.47 \\
\hline $\mathrm{Ca}^{+2} \mathrm{mg} / \mathrm{l}$ & 601 & 101 & 351 & 119.25 \\
\hline $\mathrm{Mg}^{+2} \mathrm{mg} / \mathrm{l}$ & 563 & 58 & 310.5 & 119.22 \\
\hline $\mathrm{SO}_{4}^{-2} \mathrm{mg} / \mathrm{l}$ & 2597 & 563 & 1580 & 696.67 \\
\hline $\mathrm{Na}^{+} \mathrm{mg} / \mathrm{l}$ & 1970 & 125 & 1047.5 & 464.90 \\
\hline $\mathrm{K}^{+} \mathbf{m g} / \mathbf{l}$ & 0.8 & 80 & 40.4 & 22.66 \\
\hline $\mathrm{Cl}^{*} \mathrm{mg} / \mathrm{l}$ & 1633 & 241 & 937 & 289.13 \\
\hline TSS $\mathrm{mg} / \mathrm{l}$ & 71.72 & 0.4 & 36 & 24.03 \\
\hline $\mathrm{NO}_{3}{ }^{-} \mathrm{mg} / \mathrm{l}$ & 60 & 7 & 33.5 & 22.49 \\
\hline $\mathrm{COD} \mathrm{mg} / \mathrm{l} \mathrm{O}$ & 38.4 & 1 & 19.7 & 12.33 \\
\hline BOD mg/l O & 120 & 0.7 & 60.35 & 41.9 \\
\hline
\end{tabular}

Comparing these values with the standards, we saw that these values are very high. The high conductivity of this water wells may either not to the nature of the geological layers of the aquifer, or to the presence of undesirable minerals in these water, the higher conductivity than one signal is detected in wells that are at the downtown of the valley. An influence of the flow of the river quite downstream and upstream penetrating inside the estuary, helping by the low slope of the main course, leading to a significant increase in chlorides $(1633 \mathrm{mg} \backslash \mathrm{l})$, sulphates (2597 $\mathrm{mg} \backslash \mathrm{l})$, sodium $(1970 \mathrm{mg} \backslash \mathrm{l})$, etc. This influence can be defined as a gradient of increasing mineralization 
of the entrance to the town Ghardaia (capital of the province) and at the end or it is the accumulation of Oued. This is also justified by the high values of chemical oxygen demand (38.40 $\left.\mathrm{mg} \backslash 1 \quad \mathrm{l} \mathrm{O}_{2}\right)$ downstream of the river. The value of the chemical oxygen demand "COD" obtained through the analysis appears to be low at the centre of the town of Ghardaia $\left(1 \mathrm{mg} \backslash 1 \mathrm{O}_{2}\right)$. What justifies the absence of organic material plateau is due to high salinity (cond $7.48 \mathrm{~ms} \backslash \mathrm{cm}$ ). The values set in Biological oxygen demand "BOD" is weak downstream. These values vary between 1 and $2.8 \mathrm{mg} \backslash 1$; this means that there is no organic matter because of the high salinity (6.95 and $3.14 \mathrm{~ms} \backslash \mathrm{cm})$. We found that the value of the strongest BOD $\left(120 \mathrm{mg} \backslash l \mathrm{l} \mathrm{O}_{2}\right)$ corresponds to the sampling of the wells of the township of Beni Isguen that is located below the industrial zone. The set of values of concentration of the $\mathrm{BOD}$ and $\mathrm{COD}$ are superior to the doorsteps fixed by the WHO norms. The same analysis results indicate that the biodegradability coefficient is in the range of $1<$ COD / BOD $<30.72$. The natural purification process is not effective for some points or (COD / BOD > 2). Suspended solids TSS generally related to hydrological sequences rivers (flood and low water) $[19,20]$. The spatial variation shows a marked evolution (71.72 $\mathrm{mg} \backslash \mathrm{l})$ and after falling to low levels (7.06 $\mathrm{mg} \backslash 1)$, the main course to the downstream $(0.7$ $\mathrm{mg} \backslash 1)$. As for the evolution of nitrogen forms, the analysis results reflect a chemical imbalance that is due to significant organic pollution. The presence of ammoniacal nitrogen usually translates an incomplete degradation process of organic matter. However, contributions from domestic, industrial or agricultural, should not be overlooked [21]. Nitrites are transformed into Nitrates, state the more oxidized nitrogen, show important spatio-temporal variation, and show an appreciable nitrification in the receiving environment. This is probably due to the significant turbulence that characterizes the stream and good oxygenation [22]. The results of nitrate, show a large gap between the minimum and maximum values recorded, nitrate concentrations increase upstream (26.14 $\mathrm{mg} \backslash \mathrm{l})$ and downstream (24.78 $\mathrm{mg} \backslash \mathrm{l})$, specifically a significant increase in wells $(60.1 \mathrm{mg} \backslash \mathrm{l})$ if we consider that nitrates and their derivatives from normally diffuse pollution (soil leaching) or specific (urban and industrial discharges). Moreover, we note low values into nitrites which are between 0 and 0.015 $\mathrm{mg} \backslash 1$. Nitrites are an unstable intermediate phase in the water because of its rapid biological oxidation to nitrate. Thus, its existence in water is at low doses. As for the analytical results for dissolved oxygen, the (Table 1) shows the largest fall of dissolved oxygen concentrations ( 0.04 and $4.6 \mathrm{mg} \backslash 1$.). This reflects an excessive consumption of dissolved oxygen. Furthermore, the ammonium content fluctuates between 0.00 and $1 \mathrm{mg} \backslash 1$ and the contents of orthophosphates are acceptable $(0-0.24 \mathrm{mg} \backslash 1)$. Regular observations on the analysis results show that the water from underground aquifers at the downtown of the valley is relatively loaded TSS, nitrates and salinity. This is probably due to an external supply of the aquifer by sewage infiltration. Based on the analysis results obtained in this study (Table 1), the following comments can be made:

$>$ The order of abundance of cations ( $\mathrm{mg} / \mathrm{l}$ ) obtained on these waters is:

$\mathrm{Na}^{+}>\mathrm{Ca}^{2+}>\mathrm{Mg}^{2+}>\mathrm{K}^{+}>\mathrm{NH}^{+4}$ And the anions: $\mathrm{SO}_{4}^{-2}>\mathrm{Cl}^{-}>\mathrm{HCO}^{3->} \mathrm{NO}^{3->} \mathrm{PO}_{4}{ }^{3-}$

This element of the distribution order is respected in almost all samples.

$>$ Annual variation in concentrations of $\mathrm{Na}, \mathrm{CI}$ and sulphate are in the same direction. EC indicates that these three chemical elements have the same lithological origin [23]. The saline nature of water studied is proven.

$>$ A large gap between the minimum and maximum values of the major elements (Table 1). This is due to the well depth and the nature of the geological layers of the aquifer.

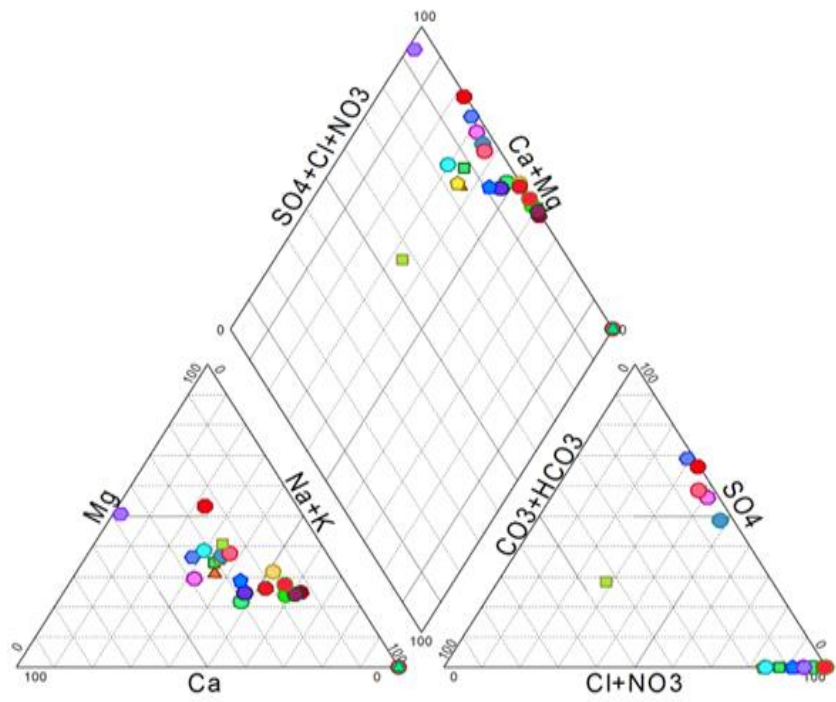

Figure 4: Representation of ground water analyses on a PIPER diagram. 
Table 2: Correlation matrix between the physico-chemical elements

\begin{tabular}{|l|c|c|c|c|c|c|c|c|c|c|c|}
\hline & $\mathrm{CE}$ & $\mathrm{Ca}^{+2}$ & $\mathrm{Mg}^{+2}$ & $\mathrm{SO}_{4}{ }^{2-}$ & $\mathrm{Cl}^{-}$ & $\mathrm{HCO}_{3}{ }^{-}$ & $\mathrm{K}^{+}$ & $\mathrm{Na}^{+}$ & $\mathrm{NH}_{4}^{+}$ & $\mathrm{NO}_{2}^{-}$ & $\mathrm{NO}_{3}{ }^{-}$ \\
\hline $\mathbf{C E}$ & 1 & & & & & & & & & & \\
\hline $\mathbf{c a}^{+2}$ & 0.698 & 1 & & & & & & & & & \\
\hline $\mathbf{M g}^{+2}$ & 0.645 & 0.72 & 1 & & & & & & & & \\
\hline $\mathbf{S O}_{4}{ }^{2-}$ & 0.601 & 0.684 & 0.861 & 1 & & & & & & & \\
\hline $\mathbf{C l}^{-}$ & 0.913 & 0.721 & 0.626 & 0.541 & 1 & & & & & & \\
\hline $\mathbf{H C O}_{3}$ & -0.207 & -0.278 & -0.193 & -0.715 & -0.188 & 1 & & & & & \\
\hline $\mathbf{K}^{+}$ & 0.695 & 0.359 & 0.182 & 0.543 & 0.546 & -0.167 & 1 & & & & \\
\hline $\mathbf{N a}^{+}$ & 0.509 & 0.408 & 0.595 & 0.478 & 0.583 & -0.347 & 0.305 & 1 & & & \\
\hline $\mathbf{N H}_{4}^{+}$ & -0.022 & -0.196 & -0.263 & 0.066 & -0.042 & -0.105 & 0.088 & -0.1 & 1 & & \\
\hline $\mathbf{N O}_{2}{ }^{-}$ & -0.252 & -0.29 & -0.258 & 0.58 & -0.216 & -0.056 & -0.133 & -0.162 & -0.074 & 1 & \\
\hline $\mathbf{N O}_{3}^{-}$ & -0.154 & -0.337 & -0.366 & 0.418 & -0.119 & -0.121 & 0 & -0.284 & -0.114 & 0.136 & 1 \\
\hline $\mathbf{O . P O}_{4}{ }^{3-}$ & -0.032 & -0.011 & -0.317 & 0.37 & -0.043 & -0.102 & 0.188 & -0.207 & 0.018 & 0.57 & 0.048 \\
\hline
\end{tabular}

The analysis in ACP have been done on physicochemical data (24 variables) In our survey, the goal of the ACP is to determine the origins and the main mechanisms of Mineralization through the interrelationships between the elements and the individuals, this analysis to summer achieves by the software spad version 5.5.The study of inter-element relationship (Table 2) shows that the electrical conductivity $(\mathrm{r}=0.913)$ and calcium $(r=0.721)$ are well correlated with chlorides, calcium with magnesium $(r=0.861)$ this strong correlation can be justified by the nature of licks and easily soluble in water rocks. The representation of groundwater analysis data on a PIPER diagram (Figure 4) shows that the majority of the water is chlorinated facies and calcium and magnesium sulphate facies and few wells on the sodium chloride and potassium facies or sodium sulphated facies [24]

\section{Conclusion}

Under the effect of significant pollution resulting from the use of fertilizers and especially discharges without prior treatments, sewage, waste is the most important cause of pollution of the groundwater in the area of $\mathrm{M}^{\prime}$ zab. The results of analysis of groundwater show very high level of dissolved salt. This excess of salt is due to the infiltration of industrial water and stagnant water through the geological layers. Moreover, the absence of the organic material is justified by high salinity. The mineralization of water is related to the geological nature of the rocks. The presence of nitrogen in the form of nitrite, nitrate and ammonium in moderate contents not affect groundwater. The absence of the phosphate content indicates that these waters are poor visà-vis the various regulated standards. The representation of groundwater analysis data PIPER diagram shows that the vast majority of the water is chlorinated facies and calcium and magnesium sulphate facies. The indicators obtained through this study present a global situation M'zab pool that is alarming. This requires the establishment of a water resources protection strategy. Moreover, downstream and in the middle, wastewater influence contributes to further damage water quality. Efforts should be made to reduce toxic substances release in the valley. This scheme should provide more treatment and less pushed all liquid and solid waste in the basin of M'zab. 


\section{How to Cite this Article:}

Z. Amer, Z. Saha, and H. Abdelkrim, "Spatio-Temporal Variation Study of Physico -Chemical Parameters Characterizing Water Quality of Oued M'zab Region, Algeria", International Annals of Science, vol. 1, no. 1, pp. 2-7, 2016. doi: 10.21467/ias.1.1.2-7

\section{References}

[1] A.Ghazi, "Desertification in Algeria: Policies and measures for the protection of natural resources: Facing Global Environmental Change Hexagon Series on Human and Environmental Security and Peace", Vol.4, Part II, pp159-173, 2009.

[2] Z. Baba amer, "Analyse d'une famille d'herbicides triazines par FT/IR et GC/MS Application à la recherche des polluants organiques dans un puits d'El Atteuf " Ghardaia" Thèse magister univ. Ouargla, 2001

[3] A. Hazzab, "Eaux minérales naturelles et eaux de sources en Algérie " C .R Géoscience 343, pp 20-31, 2011.

[4] A. Khaldi," Impacte de la sécheresse sur le régime des écoulements souterrains dans les massifs calcaires de l'ouest algérien "Monts deTlemcen- Saïda". Thèse de doctorat d'état, université d'Oran-Algérie, 2005.

[5] Y. Djellouli, P. Dage "Conséquences de la sécheresse desdeux dernières décennies sur les écosystèmes naturel salgériens". Pub Assoc Intern Climatol, 6 pp 105-14, 1993.

[6] H. Bahloul, H. M. Djellouli, S. Taleb, Z. Rezgane, A. Cheriti, A. Benghalem, "In vitro inhibitory effect of drinking water from south Algeria on the dissolution of dental hydroxyapatite"med. J. Chem. 14 , pp192- 199, 2011.

[7] Ministère ressources en eau, «agence nationale des ressources hydrauliques » Algerie, 1993.

[8] Ministère ressources en eau, " agence nationale des ressources hydrauliques » Algerie, 2003

[9] Y. Beskri, M. Belhadj aissa, F. Hosine \& A.Belhadj aissa "Extraction des indice géomorphologiques des bassins versant sàpartir du MNT. Application : Bassin versant de Oued M'zab, Algerie" Journal d'animation scientifique (JAS09) de l'AUF Alger, 2009.

[10] J. Dubief, "Le climat du sahara, institut des recherches sahariennes", mémoire hors série, tome 1 et 2 .Alger, p275, 1963

[11] K. Korichi, A. Hazzab "Hydrodynamic investigation and numerical simulation of intermittent and ephemeral flows in semi-arid regions: wadi mekerra, algeria" $J$. Hydrol. Hydromech., 60, 2, 125-142, 2012.

[12] K. Sekkoum, M. F. Talhi, A Cheriti, Y. Bourmita, N. Belboukhari, N. Boulenouar and S. Taleb "Water in Algerian Sahara: Environmental and Health impact" ,Advancing Desalination, 2012.

[13] S. SCHMIDH, "Compendium de normes ISO environnement qualité de l'eau" tome 2 Méthodes chimiques ISO, Suiss, 1994

[14] J. Rodie "L'analyse de l'eau "edition Dunod Belgique, 2009

[15] I. Gourari, M. Alaoui-mhamdi,A. Boushaba. et B.Fedan, "Variations des paramétres physico-chimiques des eaux de I'Oued Aggai: significations géo-environnementales et consequences sur la precipitation des travertins actuels (Causse de Sefrou, Moyen-Atlas - Maroc" Journal of African Earth Sciences, Vol 30, No. 2, pp 283-293, 2000.
[16] Mc Neely R. N., Neimanis V. P. et Dwyer L. "Référence sur la qualité des eaux. Guide des paramètres de la qualité des eaux. Environnement, Canada, Direction de la Qualité des Eaux", Ottawa, Canada, 1980.

[17] H. Labbardi, O.Ettahiri, S. Lazar, Z. Massik,S. El Antri "Etude de la variation spatio-temporelle des paramètres physico-chimiques caractérisant la qualité des eaux d'une lagune côtière et ses zonations écologiques : cas de moulay bousselham, maroc", Géosciences de surface (HydrologieHydrogéologie) , 2005.

[18] B.Dussart "Limnalogie: L'étude des Eaux Continentale", Paris, p736, 1992.

[19] D. Fontvieille, "La circulation du carbone organique dans les écosystèmes lotiques. Cas du phénomène d'autoépuration". Thèse Univ. LyonI,p135,1987.

[20] F.Z. Mehennaoui Afri "Contribution àl'étudedelaqualité physicochimique de l'oued Rhumel-Kebir "comptesrendus $1^{\circ}$ Séminaire sur l'environnement en Algerie, Constantine, 27-30nov. P11, 1988.

[21] J. Rodie "L'analyse de l'eau "edition Dunod Belgique, 2005.

[22] L. Bennasser, M. Fekhaouf, J.L. Benoit-Guyod Et G. Merlin, "Influence de la marine sur la qualitlé des eaux du bas sebou soumis aux rejets de la plaine du GHARB (Maroc) " Elsevier Science Ltd Vol. 31, No. 4, pp. 859867, 1997.

[23] Bernard. J, "Memonto Technique de l'eau" Edition ParisFrance, 1989.

[24] Z.Baba Amer, M. Taleb Bahmed, S. Bouchlaghem,"Impact of industrial waste on the quality of ground water in the M'Zab valley. And Evaluation of the salinity of the ground water used for irrigation in the region of El Atteuf, South Algerian "Advances in Environmental Biology, 10(6), pp: 12-20, 2016.

Publish your research article in AIJR journals-

A. Online Submission and Tracking

B. Peer-Reviewed

C. Rapid decision

D. Immediate Publication after acceptance

E. Articles freely available online

F. Retain full copyright of your article.

Submit your article at journals.aijr.in

Publish your books with AIJR publisher-

1- Publish with ISBN and DOI.

2- Publish Thesis/Dissertation as Monograph.

3- Publish Book Monograph.

4- Publish Edited Volume/ Book.

5- Publish Conference Proceedings

6- Retain full copyright of your books.

Submit your manuscript at books.aijr.org 